\title{
A Giant Primary Retroperitoneal Serous Cystadenoma: Case Report and Review of Retroperitoneal Cysts
}

\author{
Amit Mori, $\mathrm{MD}^{1}$ Kinesh Changela, $\mathrm{MD}^{1}$ \\ Ahmar Butt, $\mathrm{MD}^{2}$ Madhavi Reddy, $\mathrm{MD}^{1}$ \\ ${ }^{1}$ Division of Gastroenterology and Hepatology, The Brooklyn Hospital
Center, Clinical Affiliate of Mount Sinai Hospital, Brooklyn, New York
2 Division of Internal Medicine, The Brooklyn Hospital Center, Clinical
Affiliate of Mount Sinai Hospital, Brooklyn, New York
${ }^{3}$ Division of Surgery, The Brooklyn Hospital Center, Clinical Affiliate of
Mount Sinai Hospital, Brooklyn, New York
}

Dhuha Alhankawi, $\mathrm{MD}^{2}$ Alexander Itskovich, $\mathrm{MD}^{3}$
Surg J 2017;3:e32-e37.

\author{
Address for correspondence Amit Mori, MD, Division of \\ Gastroenterology and Hepatology, The Brooklyn Hospital Center, \\ Clinical Affiliate of Mount Sinai Hospital, 121 DeKalb Avenue, \\ Brooklyn, NY 11201 (e-mail: drabm2007@yahoo.com).
}

\begin{abstract}
Keywords

- primary

- retroperitoneal

- serous

- cystadenomas

- cystic

Primary retroperitoneal serous cystadenomas (PRSCs) are rare cystic lesions whose pathogenesis is currently not well understood. Although the vast majority of tumors are benign, early recognition and resection is necessary to avoid malignant transformation, rupture, and secondary infection. Here we present the case of a 79-year-old woman who presented with confusion, visual hallucinations, and a history of fall. As part of the work-up for abdominal distension, computed tomography scan of the abdomen and pelvis was performed, which revealed a right-sided retroperitoneal cystic lesion measuring $26.6 \times 16.7 \mathrm{~cm}$ in size. The lesion was resected laparoscopically, and the surgical specimen measured $28 \times 17 \mathrm{~cm}$. Histology revealed a serous cystadenoma. The postsurgical course was uneventful, and no radiological recurrence was noted on 3 months follow-up. Very few primary retroperitoneal cystic lesions have been reported in the literature. Most lesions are benign and predominantly occur in females. They may remain asymptomatic for long periods of time and are usually discovered when they reach very large in size. In rare cases, these lesions may have malignant potential. Diagnosis of PRSC should be considered in the differential diagnosis of all retroperitoneal cysts.
\end{abstract}

Primary retroperitoneal serous cystadenoma (PRSC) is an extremely uncommon lesion of retroperitoneum. Very few case reports of this entity have been described in the literature. The pathogenesis is not well understood, although one of the proposed hypotheses considers it to be an embryological remnant of the urogenital apparatus with epithelial and mesothelial tissues. ${ }^{1}$ These cysts oftentimes attain very large size before becoming symptomatic. Our case review is focused on the diagnostic, therapeutic, and pathological findings of this rare entity.

received

July 19, 2016 accepted after revision January 30, 2017
DOI http://dx.doi.org/ 10.1055/s-0037-1599820. ISSN $2378-5128$.

\section{Case Presentation}

A 79-year-old female presented to the emergency room with confusion, agitation, and visual hallucinations after sustaining a fall. Although the patient was a poor historian, her family members did not report prior history of abdominal complaints including trauma, fever, weight loss, abdominal mass, or surgery. Abdominal examination revealed soft, nontender, palpable fullness in the paraumbilical region. Gastroenterology service was consulted for a nontender

Copyright $\odot 2017$ by Thieme Medical Publishers, Inc., 333 Seventh Avenue, New York, NY 10001, USA Tel: +1(212) 584-4662.
License terms

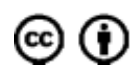




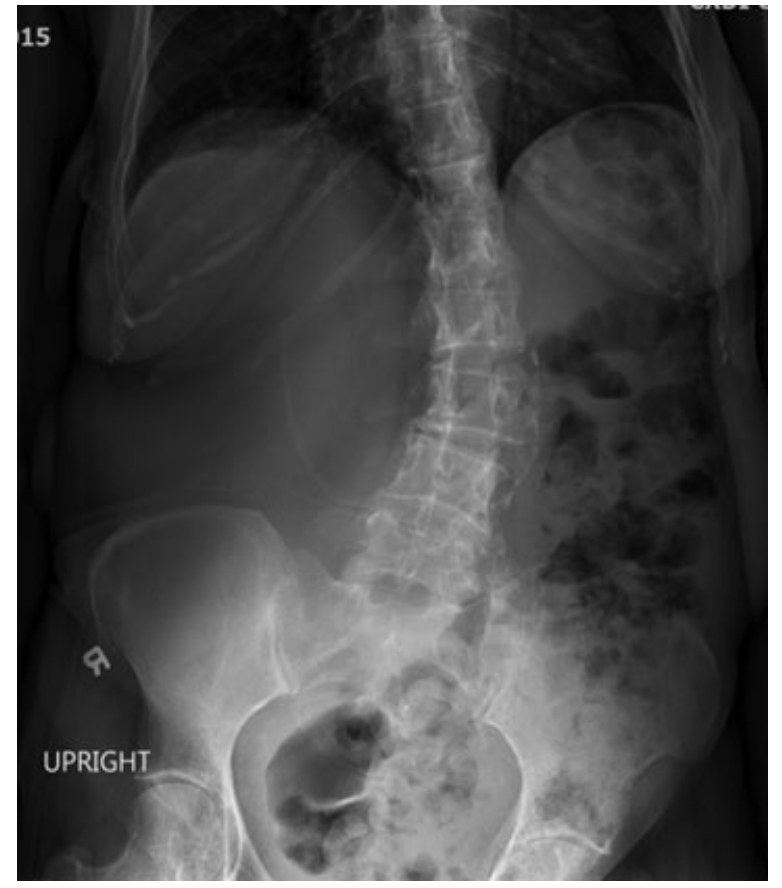

Fig. 1 Plain upright abdominal film showing displaced bowel loops to the left with large amount of stool in the colon.

abdominal fullness on physical examination as well as laboratory findings of severe iron deficiency anemia. The rest of her laboratory findings were unremarkable.

A supine and upright abdominal film showed bowel loops displaced to the left with a large amount of stool in the colon (-Fig. 1). A noncontrast computed tomography (CT) of the abdomen and pelvis revealed a large right retroperitoneal cystic structure measuring at least $26.6 \times 11.7 \times 16.7 \mathrm{~cm}$. The cyst was displacing the right kidney and right colon medially ( - Figs. 2 and $\mathbf{3}$ ). These findings were consistent with a giant retroperitoneal cyst (RPC). Though her presenting complaints were attributed to her history of fall with possible concussion, the diagnosis of RPC was found via thorough physical exam revealing a large, palpable abdominal mass.

The patient was taken to the operating room with a high suspicion that the CT findings were consistent with a giant liver cyst. Upon entering the abdomen using a Hasson technique and placing a $12-\mathrm{mm}$ trocar, a diagnostic laparoscopy revealed a large cyst with a blue hue. Given that the CT findings showed no evidence of nodularity, septation, or intracystic masses and the laparoscopic findings were consistent, the suspicion of malignancy was very low. Upon drainage of the cyst, it was clearly noted that it was easily separable from the posterior liver and was in fact retroperitoneal in origin. The posterior peritoneum was incised. The wall of the cyst was carefully dissected from the anterolateral wall of the kidney, adrenal, and the posterior wall of the ascending colon keeping in mind the significant distortions in anatomy secondary to its size. A plane between the cyst and the posterior peritoneum was established, and the cyst was separated using a combination of electrocautery and sharp dissection. The cyst was then placed in an endocatch bag and removed through the $12-\mathrm{mm}$ port. Thus, the

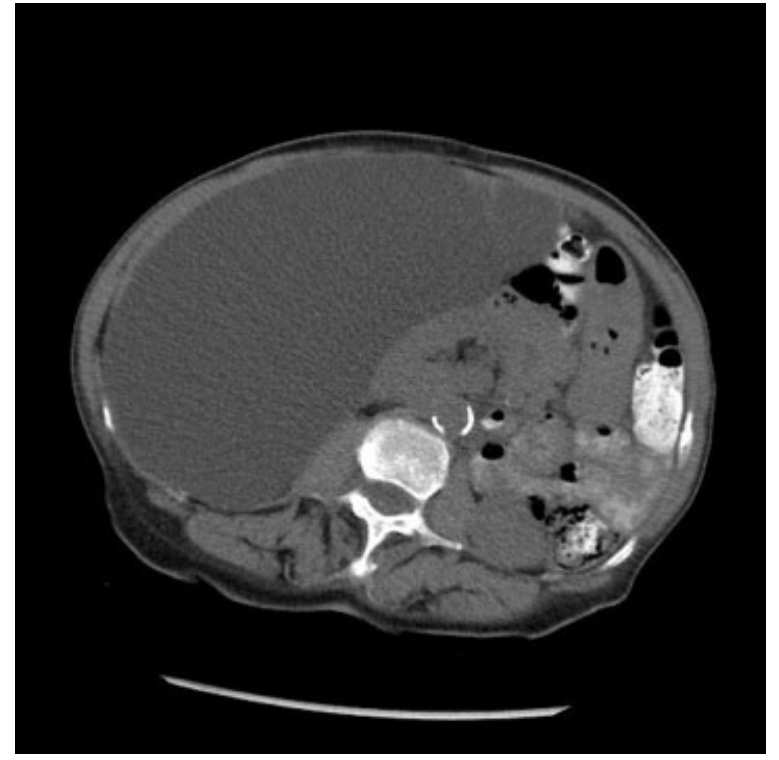

Fig. 2 Abdominal computed tomography shows a large right retroperitoneal cystic lesion with displacement of the right kidney and bowel loops to the left.

patient underwent a complete cyst excision using a laparoscopic transperitoneal approach. Intraoperatively, the retroperitoneal location of the cyst was confirmed as the cyst wall was separated from visceral peritoneum with ease (-Fig. 4). Macroscopically, the cyst appeared to have thick walls and measured approximately $28 \times 17 \mathrm{~cm}$ in size and containing $6 \mathrm{~L}$ of clear liquid ( - Fig. 5). Histopathology revealed a benign serous cystadenoma ( $\mathbf{- F i g .} \mathbf{6}$ ). Should there have been a preoperative suspicion of malignancy based on imaging or, diagnostic laparoscopy, an open approach with en bloc resection would have been undertaken. A subsequent CT

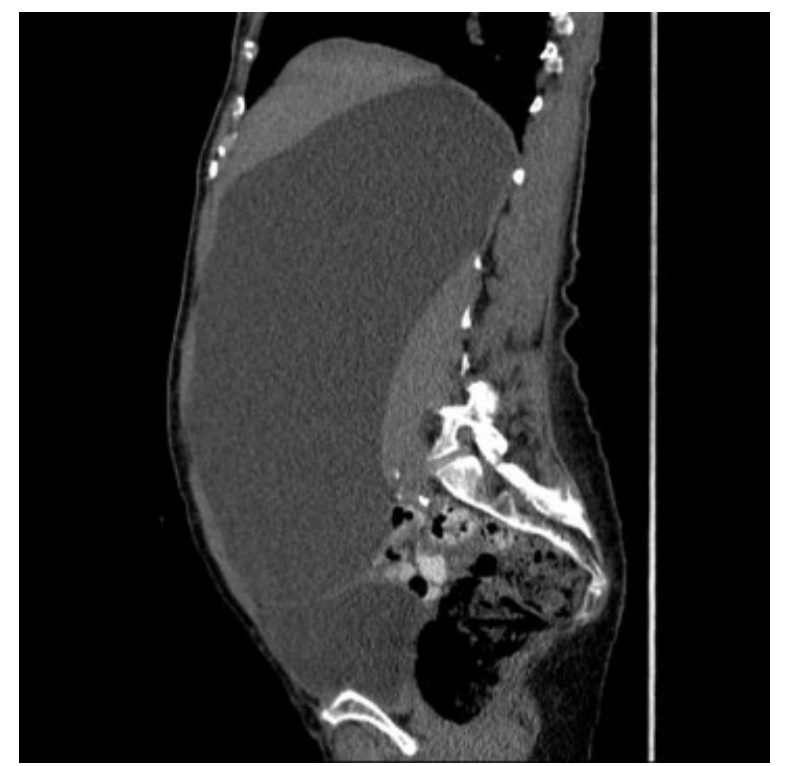

Fig. 3 Abdominal computed tomography (sagittal plane) showing a giant retroperitoneal cyst. 


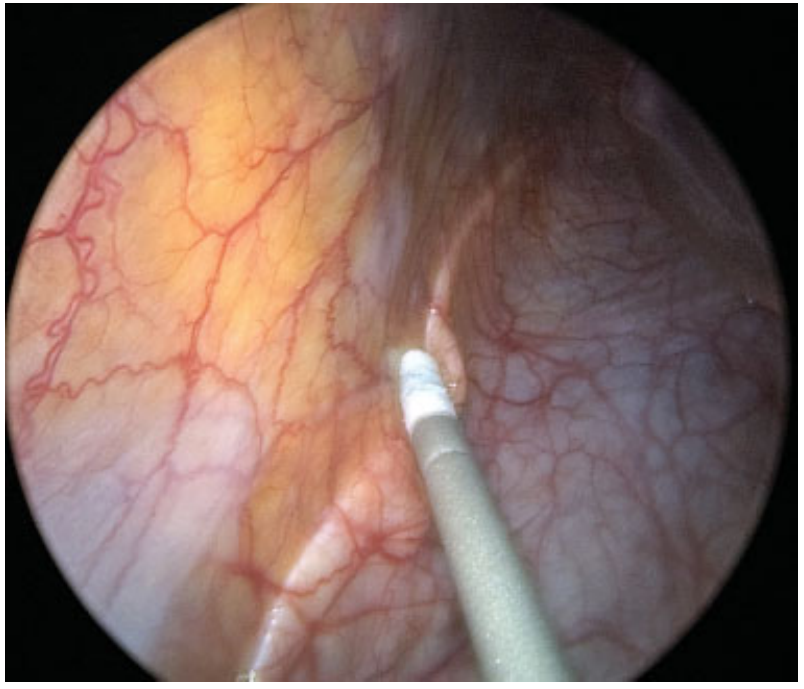

Fig. 4 Laparoscopic view of the cyst wall noted behind the posterior peritoneum.

revealed interval removal of large RPC with properly repositioned loops of bowel. The patient followed up in 3 months with no further surgical complications or recurrence. We believe that the patient's presenting symptoms were attributable to her fall, concussion, and dehydration that resolved with hydration and supportive therapy and not related to the findings of RPC or its surgical removal.

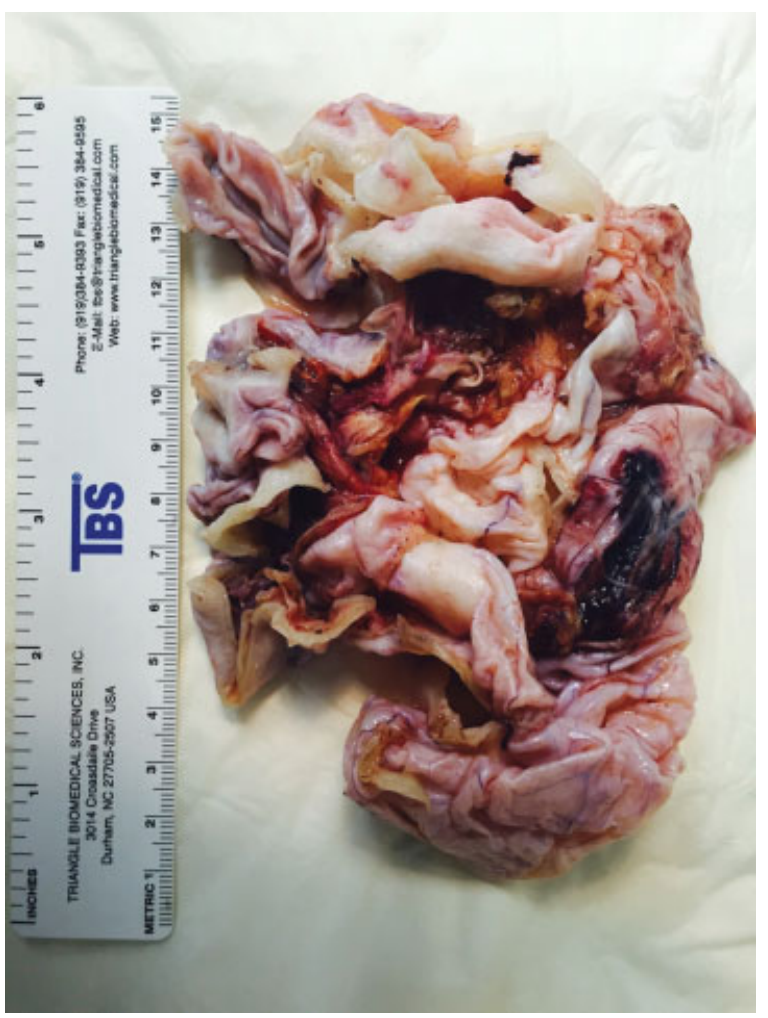

Fig. 5 Macroscopic view of the surgical specimen shows thick cystic wall.
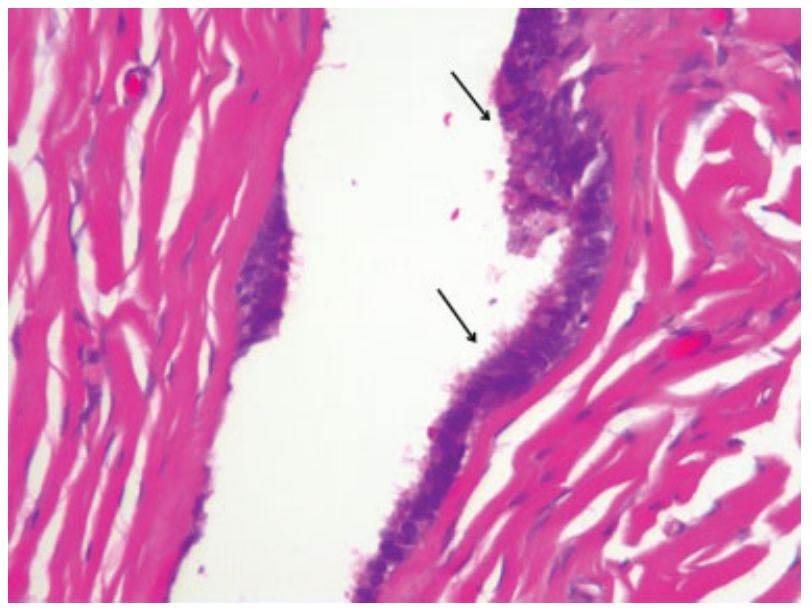

Fig. 6 Serous cystadenoma: fibrous tissue lined by mostly single-layer cuboidal or columnar serous epithelium (arrows) with tubal metaplasia. There is no ovarian tissue or mucinous epithelium. No cellular atypia (H \& E x 100).

\section{Discussion}

The retroperitoneal space is bounded anteriorly by the posterior part of parietal peritoneum, posteriorly by the psoas and quadratus lumborum muscles, as well as the spine, superiorly by the diaphragm, and inferiorly by the muscular wall of the pelvis. ${ }^{1}$ The large size of this space enables lesions to grow and remain asymptomatic for a long period of time. Only those cysts derived from this space without direct contact with other anatomical organs are included in the category of RPCs and are discussed here. Retroperitoneal cystadenoma was first described by Staehlin in 1915 . $^{2}$ Although primary retroperitoneal mucinous cystadenoma is more common, to our knowledge, there are only a few cases of PRSC that have been described in the literature. ${ }^{3-8}$ Sharatz et al reported the largest case of benign serous type cystadenoma measuring $18.7 \times 15.4 \times 10 \mathrm{~cm}^{5}$; our case is the largest reported PRSC in the literature.

Primary retroperitoneal cystic lesions are extremely rare because of a lack of epithelial cells in this region. Their incidence is difficult to estimate. The pathogenesis of primary RPCs is not well understood. Several hypotheses are described in the literature, such as: (1) coelomic epithelial metaplasia, ${ }^{9}$ (2) remnants of embryonal urogenital apparatus (pronephric, mesonephric, metanephric, and Mullerian, depending on their cell line of origin $),{ }^{10}(3)$ heterotopic ovarian tissue, ${ }^{7}(4)$ germ cell layers (cystic teratomas), ${ }^{11}$ and (5) enteric duplication cyst. ${ }^{12}$ Based on their etiology RPCs can be further divided into traumatic (urinoma, hematoma), parasitic, lymphatic, and cystic changes of a solid neoplasm (e.g., neurilemmoma, paraganglioma, sarcoma). Based on their malignant potential, RPCs can be neoplastic and nonneoplastic ( Table 1). ${ }^{13,14}$ Our literature review also reveals that based on their clinical course and microscopic appearance, primary retroperitoneal epithelial lesions can be further classified into benign (serous and mucinous cystadenoma), lesions with borderline malignancy, ${ }^{3}$ and malignant (serous and mucinous cystadenocarcinoma). ${ }^{15}$ 
Table 1 Classification and characteristics of retroperitoneal cystic lesions

\begin{tabular}{|c|c|c|c|}
\hline Type of lesion & Gender & Imaging appearance & Demographic features \\
\hline $\begin{array}{l}\text { Serous/mucinous } \\
\text { cystadenoma }\end{array}$ & Female & $\begin{array}{l}\text { Homogeneous, unilocular, thin-walled } \\
\text { cystic mass }\end{array}$ & $\begin{array}{l}\text { Symptoms based on size, very low risk } \\
\text { of recurrence with complete cyst } \\
\text { excision, rarely elevated CA } 125 \text { and } \\
\text { CA19-9 levels in the clear fluid } 15,16\end{array}$ \\
\hline Mullerian cyst ${ }^{\mathrm{a}}$ & Female & $\begin{array}{l}\text { Unilocular or multilocular, thin walled } \\
\text { with clear fluid }\end{array}$ & $\begin{array}{l}\text { Obese patients, history of irregular } \\
\text { menses, microscopically cyst wall has } \\
\text { thick smooth muscle and columnar } \\
\text { epithelial cells }\end{array}$ \\
\hline Cystic teratoma ${ }^{a}$ & $\begin{array}{l}\text { Both genders } \\
\text { with little female } \\
\text { predominance }\end{array}$ & $\begin{array}{l}\text { Hypoattenuating fat within the cyst } \\
\text { with sometimes typical wall } \\
\text { calcifications }\end{array}$ & $\begin{array}{l}\text { Mixed germline tissue on microscopy, } \\
\text { young age, low malignant potential }\end{array}$ \\
\hline $\begin{array}{l}\text { Cystic } \\
\text { lymphangioma }\end{array}$ & Male & $\begin{array}{l}\text { Large, elongated, multilocular, } \\
\text { thin-walled, complex cystic mass, may } \\
\text { cross into adjacent compartment }\end{array}$ & $\begin{array}{l}\text { Clear or milky fluid, single layer of } \\
\text { endothelial cells with lymphoid } \\
\text { aggregates }\end{array}$ \\
\hline $\begin{array}{l}\text { Cystic } \\
\text { mesothelioma }^{a}\end{array}$ & Female & $\begin{array}{l}\text { Unilocular or multilocular thin- walled } \\
\text { cyst }\end{array}$ & $\begin{array}{l}\text { Not related to prior asbestos exposure, } \\
\text { thin-walled cysts with watery fluid on } \\
\text { pathology, potential for local } \\
\text { recurrence but no metastases }\end{array}$ \\
\hline Tailgut cyst $^{\mathrm{a}}$ & Female & $\begin{array}{l}\text { Well-defined, multicystic mass with } \\
\text { wide range of attenuation, thick walled } \\
\text { if infected, may compress rectum, rare } \\
\text { thin calcifications }\end{array}$ & $\begin{array}{l}\text { Embryonic hindgut in origin, occurs } \\
\text { between rectum and sacrum. } \\
\text { Microscopically, cyst wall may show } \\
\text { several different types of epithelium. } \\
\text { Middle-aged women may be } \\
\text { complicated by infection and/or } \\
\text { malignant transformation }\end{array}$ \\
\hline $\begin{array}{l}\text { Omental/ } \\
\text { mesenteric cyst }\end{array}$ & Both genders & $\begin{array}{l}\text { Thin or thick-walled, uni- or } \\
\text { multilocular, anywhere from } \\
\text { duodenum to the rectum }\end{array}$ & $\begin{array}{l}\text { Bimodal age distribution (pediatrics } \\
\text { and middle aged), small bowel } \\
\text { mesentery origin more common }\end{array}$ \\
\hline Epidermoid cyst $^{\mathrm{a}}$ & Female & $\begin{array}{l}\text { Thin-walled, unilocular with fluid } \\
\text { attenuation, presacral retroperitoneal } \\
\text { location }\end{array}$ & $\begin{array}{l}\text { Ectodermal in origin, may occur } \\
\text { anywhere, middle-aged women, may } \\
\text { present with local mass effect (e.g., } \\
\text { pain, palpable mass). Microscopically } \\
\text { has stratified squamous epithelium } \\
\text { with mixture of water, keratin, skin } \\
\text { debris, cholesterol }\end{array}$ \\
\hline Paraganglioma ${ }^{a}$ & $\begin{array}{l}\text { Slight female } \\
\text { predominance }\end{array}$ & $\begin{array}{l}\text { Homogenous, soft-tissue attenuation } \\
\text { or central areas of low attenuation, } \\
\text { rarely with internal hemorrhage } \\
\text { subsequently forming thick capsule } \\
\text { mimicking cystic lesion }\end{array}$ & $\begin{array}{l}\text { Arise from neural crest cells and } \\
\text { sympathetic chain, may produce } \\
\text { catecholamines and lead to } \\
\text { hypertension, middle-aged patient, } \\
\text { autosomal dominant and may be } \\
\text { associated with MEN syndrome }\end{array}$ \\
\hline Neurilemmoma $^{a}$ & Female & $\begin{array}{l}\text { Thick-walled, located in paravertebral } \\
\text { space or pelvic retroperitoneum }\end{array}$ & $\begin{array}{l}\text { Encapsulated tumor from peripheral } \\
\text { nerve sheaths (Schwann cells), } 20-50 \text { y } \\
\text { of age, may be associated with } \\
\text { neurofibromatosis type-1 }\end{array}$ \\
\hline Urinoma $^{\mathrm{b}}$ & Both genders & $\begin{array}{l}\text { CT and MRI show water attenuated } \\
\text { fluid collection, hypointense } \\
\text { T1-weighted and hyperintense } \\
\text { T2-weighted images on MRI, IVP shows } \\
\text { contrast extravasation into } \\
\text { retroperitoneal tissues }{ }^{16}\end{array}$ & $\begin{array}{l}\text { History of blunt trauma, usually } \\
\text { located in perirenal space, usually has } \\
\text { associated hydronephrosis, } \\
\text { percutaneous drainage is diagnostic } \\
\text { and therapeutic }\end{array}$ \\
\hline Hematoma $^{\mathrm{b}}$ & Both genders & $\begin{array}{l}\text { Unenhanced CT shows abnormal soft } \\
\text { tissue density that may compress } \\
\text { adjacent structures, spiral CT better in } \\
\text { assessing acute active bleed as it shows } \\
\text { a jet of contrast extravasation }{ }^{23}\end{array}$ & $\begin{array}{l}\text { History of trauma, coagulopathy, } \\
\text { ruptured aortic aneurysm. } \\
\text { Conservative management in small, } \\
\text { stable hematomas. Surgical } \\
\text { management for large, unstable } \\
\text { hematomas }\end{array}$ \\
\hline
\end{tabular}


Table 1 (Continued)

\begin{tabular}{|l|l|l|l|}
\hline Type of lesion & Gender & Imaging appearance & Demographic features \\
\hline $\begin{array}{l}\text { Pancreatic } \\
\text { pseudocyst }\end{array}$ & Both genders & $\begin{array}{l}\text { Well-circumscribed, usually round or } \\
\text { oval peripancreatic fluid collections of } \\
\text { homogeneously low attenuation that } \\
\text { are usually surrounded by a well- } \\
\text { defined enhancing wall }\end{array}$ & $\begin{array}{l}\text { Clinical history of pancreatitis, } \\
\text { abdominal pain or palpable mass, } \\
\text { elevated amylase and lipase levels in } \\
\text { blood test } \\
\text { Large symptomatic cysts require } \\
\text { endoscopic, percutaneous or surgical } \\
\text { drainage. }\end{array}$ \\
\hline $\begin{array}{l}\text { Nonpancreatic } \\
\text { pseudocyst }\end{array}$ & Both genders & $\begin{array}{l}\text { Unilocular or multilocular fluid-filled } \\
\text { complex cystic lesions with thick } \\
\text { walls }{ }^{\text {b }}\end{array}$ & $\begin{array}{l}\text { Rare lesions arising from mesentery } \\
\text { and omentum. } \\
\text { May contain serous or purulent fluid } \\
\text { with or without blood. Microscopically, } \\
\text { cyst wall lacks cell lining and consists of } \\
\text { connective tissue with chronic } \\
\text { inflammatory changes }\end{array}$ \\
\hline Lymphocele
\end{tabular}

Abbreviations: CT, computed tomography; IVP, intravenous pyelogram; MEN, multiple endocrine neoplasia; MRI, magnetic resonance imaging.

${ }^{\mathrm{a}}$ Neoplastic.

${ }^{\mathrm{b}}$ Nonneoplastic.

Clinical presentation of retroperitoneal cystic lesions may vary depending on their location and size. Most commonly, cysts present as a palpable mass or abdominal pain. Constitutional symptoms such as fever, changes in appetite, and weight loss may be present especially in malignant lesions. Our patient had a palpable mass on examination, leading to the further work-up and diagnosis.

There are no pathognomonic signs, symptoms, and laboratory or imaging findings reported in the literature to confirm the diagnosis. However, few case reports suggest association with elevated blood levels of carcinoembryonic antigen (CEA), fetoprotein, CA125, CA19-9, and CA15-3. ${ }^{6,8,15-17}$ There are also case reports that may suggest some diagnostic value of the presence of CA125, CA19-9, ${ }^{8}$ and CEA ${ }^{15}$ in the aspirated cystic fluid. Certain imaging features that may suggest retroperitoneal location include location of the lesion posterior to the psoas muscle, anterior displacement of the rectum as well as anterior or medial displacement of major iliac vessels, ureter, and the iliopsoas muscle. It is suggested that magnetic resonance imaging (MRI) is a better modality than CT in identifying retroperitoneal lesions as it allows better assessment of the presence or absence of enhancing internal septae and mural nodules, and provides high quality internal signal intensity. The lesion's local extent and nonovarian origin is also better visualized on MRI. ${ }^{18}$ Although cross-sectional imaging is very helpful in providing preoperative assessment, most retroperitoneal lesions are defined during surgery. Macroscopically, the cyst wall could be smooth, stratified, thin or thick, or fibrous, depending on their origin. Additionally, the fluid could be clear, mucinous, or milky, depending on the etiology.

PRSC should be differentiated from other forms of cystic retroperitoneal lesions based on history and microscopic appearance, as well as its malignant form cystadenocarcinoma (-Table 1). Lee at al reviewed 56 cases of primary cystic mucinous neoplasms and reported that the presence of solid nodules in the cyst was the only statistically significant predictive factor of malignancy (cystadenocarcinoma). ${ }^{19}$

Diagnostic fluid aspiration is discouraged due to concerns of seeding during the procedure if the lesion is malignant. The treatment of choice is complete surgical excision. The type of surgical intervention depends on the location, size, and expertise of the surgeon. Historically, laparotomy and complete cyst enucleation has been the recommended treatment approach. However, laparoscopic cyst excision is becoming more popular in recent years. Marsupialization and partial excision of the cysts or fluid drainage are avoided given higher risks for recurrence as well as the need for repeat surgical procedures. Obscure walls and location in close proximity of major blood vessels and organs are the main challenges during RPC excision. Recurrence can occur in approximately $25 \%$ of cases of RPCs according to a case series. ${ }^{20}$ In our case, we have used laparoscopic approach with complete cyst excision. In cases of cystadenocarcinoma originating from the female reproductive organs, several case reports suggest empiric total abdominal hysterectomy and bilateral salpingo-oophorectomy with or without adjuvant chemotherapy. ${ }^{21,22}$

\section{Conclusion}

PRSCs are extremely rare lesions and oftentimes remain asymptomatic until they attain a very large size. Although advances in CT and MRI techniques enable us to identify various cystic lesions of the retroperitoneum, the exact 
diagnosis is based on histology and requires high clinical suspicion as well as expertise. We believe that endoscopic ultrasound may have a promising role in diagnosis, although further large prospective studies are required to confirm that. All attempts should be made to completely remove the cysts as risk of recurrence is high in partially excised lesions. Malignant lesions should be treated more aggressively with radical surgery and chemotherapy. More research is needed to better understand the pathogenesis of this entity.

Funding

None.

\section{Author Contribution}

Amit Mori contributed in concept and design, acquisition of available literature, drafting of the review article and approval of the scientific paper to be published. Kinesh Changela contributed in literature search, drafting and review of the manuscript, and approval of the version to be published. Dhuha Alhankawi contributed in data collection and interpretation, acquisition of available literature, and review of the manuscript. Alexander Itskovich contributed in performing surgical procedure, data collection and interpretation, and drafting and review of the manuscript. Ahmar Butt and Madhavi Reddy contributed in critical revision of the manuscript for important intellectual content

\section{Conflict of Interest}

The authors declare no conflict of interest.

\section{References}

1 Adams JT. Abdominal wall, omentum, mesentery and retroperitoneum. Schwartz SI, Shires GT, Spencer FC. Principles of Surgery. 5th ed. New York, NY: McGraw Hill; 1989:1491-1524

2 Staehlin E. A study of multilocular cystadenomata of retroperitoneal origin. Ann Surg 1915;61(03):312-323

3 Popkharitov A, Matev A, Popkharitov Ts, et al. Primary retroperitoneal serous cystadenoma with borderline malignancy: a case report and review of the literature. Trakia J Sci 2013; 4:368-373

4 Lenzi G. Serous retroperitoneal cystadenoma on an ectopic ovary with homolateral müllerian deficiency [in Italian]. Arch De Vecchi Anat Patol 1973;59(02):365-370

5 Sharatz SM, Treviño TA, Rodriguez L, West JH. Giant serous cystadenoma arising from an accessory ovary in a morbidly obese 11-year-old girl: a case report. J Med Case Reports 2008;2:7

6 Kaku M, Ohara N, Seima Y, et al. A primary retroperitoneal serous cystadenocarcinoma with clinically aggressive behavior. Arch Gynecol Obstet 2004;270(04):302-306
7 Caruncho M, Pombo F, Arnal-Monreal F. Primary retroperitoneal serous cystadenocarcinoma of 'ovarian-type': US and CT findings. Eur J Radiol 1993;17(02):115-116

8 Sanefuji T. Retroperitoneal cystadenoma containing elevated concentrations of CA125 and CA19-9 in the cyst fluid: a case report [in Japanese]. Hinyokika Kiyo 2000;46(07):457-461

9 Lauchlan SC. Metaplasias and neoplasias of Müllerian epithelium. Histopathology 1984;8(04):543-557

10 Lee J, Song SY, Park CS, Kim B. Müllerian cysts of the mesentery and retroperitoneum: a case report and literature review. Pathol Int 1998;48(11):902-906

11 Davidson AJ, Hartman DS, Goldman SM. Mature teratoma of the retroperitoneum: radiologic, pathologic, and clinical correlation. Radiology 1989;172(02):421-425

12 Abascal J, Ardaiz J, Gil P, Menéndez J, Barreiro JJ, Inchausti JL. Primary retroperitoneal cyst (possible intestinal origin) [in Spanish]. Rev Esp Enferm Apar Dig 1977;51(07):819-828

13 Alzaraa A, Mousa H, Dickens P, Allen J, Benhamida A. Idiopathic benign retroperitoneal cyst: a case report. J Med Case Reports 2008;2:43

14 Yang DM, Jung DH, Kim H, et al. Retroperitoneal cystic masses: CT, clinical, and pathologic findings and literature review. Radiographics 2004;24(05):1353-1365

15 Motoyama T, Chida T, Fujiwara T, Watanabe H. Mucinous cystic tumor of the retroperitoneum. A report of two cases. Acta Cytol 1994;38(02):261-266

16 Sebastià C, Quiroga S, Boyé R, Cantarell C, Fernandez-Planas M, Alvarez A. Helical CT in renal transplantation: normal findings and early and late complications. Radiographics 2001;21(05): 1103-1117

17 Bifulco G, Mandato VD, Giampaolino P, et al. Huge primary retroperitoneal mucinous cystadenoma of borderline malignancy mimicking an ovarian mass: case report and review. Anticancer Res 2008;28(4C):2309-2315

18 Shanbhogue AK, Fasih N, Macdonald DB, Sheikh AM, Menias CO, Prasad SR. Uncommon primary pelvic retroperitoneal masses in adults: a pattern-based imaging approach. Radiographics 2012; 32(03):795-817

19 Lee SE, Oh HC, Park YG, Choi YS, Kim MK. Laparoscopic excision of primary retroperitoneal mucinous cystadenoma and malignant predicting factors derived from literature review. Int J Surg Case Rep 2015;9:130-133

20 Kurtz RJ, Heimann TM, Holt J, Beck AR. Mesenteric and retroperitoneal cysts. Ann Surg 1986;203(01):109-112

21 Lee IW, Ching KC, Pang M, Ho TH. Two cases of primary retroperitoneal mucinous cystadenocarcinoma. Gynecol Oncol 1996; 63(01):145-150

22 de León DC, Pérez-Montiel D, Chanona-Vilchis J, Dueñas-González A, Villavicencio-Valencia V, Zavala-Casas G. Primary retroperitoneal mucinous cystadenocarcinoma: report of two cases. World J Surg Oncol 2007;5:5

23 Becker CD, Mentha G, Schmidlin F, Terrier F. Blunt abdominal trauma in adults: role of CT in the diagnosis and management of visceral injuries. Part 2: gastrointestinal tract and retroperitoneal organs. Eur Radiol 1998;8(05):772-780

24 Kim YH, Saini S, Sahani D, Hahn PF, Mueller PR, Auh YH. Imaging diagnosis of cystic pancreatic lesions: pseudocyst versus nonpseudocyst. Radiographics 2005;25(03):671-685

25 Kim JK, Jeong YY, Kim YH, Kim YC, Kang HK, Choi HS. Postoperative pelvic lymphocele: treatment with simple percutaneous catheter drainage. Radiology 1999;212(02):390-394 